\title{
Do marine reserves export adult fish biomass? Evidence from Apo Island, central Philippines
}

\author{
Garry R. Russ ${ }^{1, *}$, Angel C. Alcala ${ }^{2}$ \\ ${ }^{1}$ Department of Marine Biology, James Cook University of North Queensland, Townsville, Queensland 4811, Australia \\ ${ }^{2}$ Department of Environment and Natural Resources, Visayas Avenue, Diliman, Quezon City 1100, The Philippines
}

\begin{abstract}
A frequent expectation of the use of marine reserves in management of coral reef fisheries is maintenance or enhancement of yields to areas adjacent to reserves by adult (post-settlement) movements from reserve to fished areas (the so-called 'spillover effect'). Demonstration of this effect has been rare. This paper reports on some circumstantial evidence derived from underwater visual census monitoring of densities of large predatory coral reef fish [Serranidae (Epinephelinae), Lutjanidae, Lethrinidae and Carangidae as a group inside and adjacent to a small marine reserve at Apo Island in the central Philippines over a 10 yr period (1983 to 1993). The marine reserve (sanctuary) at Apo Island was established in 1982 and was protected from fishing for the duration of the study. The non-reserve area was open to fishing by up to 200 municipal fishers using traditional fishing gear (bamboo traps, hooks and lines, gill nets and spears). Significant positive correlations of both mean density and species richness of large predatory fish with duration of reserve protection (from 1 to $11 \mathrm{yr}$ ) were observed in both the reserve and non-reserve areas surveyed. The minimum distance from the boundary of the reserve to the non-reserve area surveyed was $200 \mathrm{~m}$. During the first $8 \mathrm{yr}$ of reserve protection combined, the density of large predatory fish at distances 200 to 300,300 to 400 and 400 to $500 \mathrm{~m}$ from the reserve boundary did not differ significantly from an even distribution (chi-squared test, $p>0.05$ ). During the period of 9 to 11 yr of protection combined, there was a significantly higher density of these fish in the area closest to the reserve (i.e. in the 200 to $300 \mathrm{~m}$ area, chi-squared test, $\mathrm{p}<0.05$ ). This visual census data is consistent with a proposed model of adult fish export from the reserve to the non-reserve areas. Along with interview data collected in 1986 and 1992 that showed that fishers were unanimous that their yields had increased since the reserve was implemented, this study provides evidence for export of adult fish from reserve to fished areas.
\end{abstract}

KEY WORDS: Marine reserves Spillover effect - Fish export . Coral reef fish Fisheries management. Philippines

\section{INTRODUCTION}

In recent years, the potential use of marine reserves lareas of the marine environment protected from various forms of exploitation by humans, principally fishing) in the management of fisheries on coral reefs has received considerable attention (e.g. Davis \& Dodrill 1989, Alcala \& Russ 1990, Bohnsack 1990, 1993, Polacheck 1990, Roberts \& Polunin 1991, 1993, Carr \& Reed 1993, DeMartini 1993, Dugan \& Davis 1993. Polunin \& Roberts 1993, Rowley 1994). The major objectives (amongst many others) of the use of marine reserves in management of coral reef fisheries is pro-

•E-mail: garry.russ@jcu.edu.au tection of a critical spawning stock biomass to ensure recruitment supply to fished areas via larval dispersal and possible maintenance or enhancement of yields to areas adjacent to reserves by adult (post-settlement) movements (e.g. Alcala \& Russ 1990, Bohnsack 1990 , 1993, Roberts \& Polunin 1991, 1993, Dugan \& Davis 1993). Much of this interest stems from the difficulties of administering more conventional fisheries management programs in coral reef fisheries (Bohnsack 1990, Polunin 1990, Roberts \& Polunin 1991, 1993, Russ 1991). Alcala \& Russ (1990) argued that control of fishing effort by marine reserves appears to be one of the few viable options available to managers of marine municipal fisheries in the Philippines, where 10 to $15 \%$ of total fisheries yield is taken from coral reefs (Car- 
penter 1977, Murdy \& Ferraris 1980, McManus 1988). It is generally agreed that protection of a critical minimum spawning stock biomass to guard against recruitment overfishing is likely to be the primary benefit of marine reserves in a fisheries management context (Davis \& Dodrill 1989, Bohnsack 1990, 1993, Roberts \& Polunin 1991, 1993, Russ et al. 1992, DeMartini 1993. Dugan \& Davis 1993, Polunin \& Roberts 1993). However, a substantial amount of research is still required to assess the effects of marine reserves on recruitment levels at broad spatial scales (Carr \& Reed 1993, Man et al. 1995). If such recruitment benefits do occur, they will tend to apply at the larger spatial scale of the stock since larvae may disperse great distances. The net effect of maintaining recruitment is also maintenance of fisheries yield at the local village scale. This type of fisheries maintenance should be distinguished from export of post-settlement fish across reserve boundaries, the so-called 'spillover effect' (e.g. Davis 1981, Alcala \& Russ 1990, Bohnsack 1990, Yamasaki \& Kuwahara 1990, DeMartini 1993, Dugan \& Davis 1993, Rowley 1994).

Establishment of marine reserves, particularly in the developing world, almost invariably requires the strong support of the local people living in and adjacent to the area concerned (e.g. Cabanban \& White 1981, White 1988, White et al. 1994). In many cases, promises of 'stock wide' (i.e. recruitment) rather than local (i.e. spillover) benefits can appear rather nebulous. It is a common assumption, not just of local people but often of the community-based managers encouraging establishment of marine reserves, that fish populations will increase in the reserve and breed successfully and that this will have direct benefits for fished areas nearby because both adults and their young will move out from the reserve. Convincing a village or island community that a marine reserve may benefit the reef fisheries 10 to $100 \mathrm{~km}$ downstream (since that is where the larvae are likely to go) is inevitably difficult. Thus, any demonstration that marine reserves may affect nearby fisheries in a positive manner, even if the effect is only minor, may be critical to the successful establishment of community-based marine reserves.

Demonstrations of export of adult biomass of target species from reserve to fished areas coupled with evidence of actual positive effects on local fisheries yield are rare (Alcala \& Russ 1990, Yamasaki \& Kuwahara 1990). Several studies have used tag-recapture techniques and reported movements of target species from reserve to fished areas, e.g. lobsters (Davis \& Dodrill 1980, 1989), shrimps (Gitschlag 1986), snow crabs (Yamasaki \& Kuwahara 1990) and reef fish (Beinssen 1989, 1990, Bryant et al. 1989, Rutherford et al. 1989, Attwood \& Bennet 1994, Davies 1995). In addition, studies have modeled the potential effects of movements of adult fish from marine reserve to fished areas on yield per recruit of target species (Polacheck 1990, Russ et al 1992, DeMartini 1993) and suggested that such fisheries enhancement effects may be possible under certain conditions.

This paper reports on some circumstantial evidence of export of adult fish biomass from a reserve to an adjacent fished site derived from underwater visual census monitoring of densities of large predatory coral reef fish [Serranidae (Epinephelinae), Lutjanidae, Lethrinidae and Carangidae as a groupl inside and adjacent to a small marine reserve at Apo Island in the central Philippines over 10 yr (1983-1993).

\section{MATERIALS AND METHODS}

Study sites. The study was carried out on sections of the fringing reef slope at Apo Island, southeast of Negros (9 $9^{\circ} 4^{\prime} \mathrm{N}, 123^{\circ} 16^{\prime}$ E), central Philippines (Fig. 1). Apo Island had a marine reserve established on its southeastern side in late 1982; it is a mainland island of $0.7 \mathrm{~km}^{2}$ surrounded by $1.06 \mathrm{~km}^{2}$ of fringing coral reef to the $60 \mathrm{~m}$ isobath $\left(0.7 \mathrm{~km}^{2}\right.$ to the $20 \mathrm{~m}$ isobath). The 2 sites studied at Apo Island were the reserve, a $0.45 \mathrm{~km}$ section (approximately 10\% of the coral reef area) of the southeastern side of the island, and a section outside the reserve on the southwestern side of the island (Fig. 1). The distance from the southern boundary of the reserve to the start of the area censused outside the reserve (see below) was approximately $200 \mathrm{~m}$ (Fig, 1). The reef crest within the reserve was at a depth of 6 to $7 \mathrm{~m}$. The reef crest and slope consisted of consolidated limestone with a high cover of living coral. The angle of the slope was approximately 50 to $60^{\circ}$ to a depth of $17 \mathrm{~m}$. Overhanging ledges occurred at depths of 9 to $17 \mathrm{~m}$. The non-reserve site at Apo Island had a crest at a depth of 5 to $7 \mathrm{~m}$ and a reef slope at an angle of 35 to $40^{\circ}$ to $14 \mathrm{~m}$. The crest and slope were consolidated limestone overlaying a base of volcanic rock. There was a relatively high percentage cover of living corals, particularly soft corals. There were few ledges at this site.

Apo Island has approximately 500 permanent residents. Silliman University in Dumaguete City, Negros, began a marine conservation and education program on the island in 1979, and in 1982 an agreement was reached between the town of Dauin (which has municipal jurisdiction over the island), the people of the island and Silliman University to implement a nofishing area (marine reserve or sanctuary) This reserve area was protected by the community itself from 1982, although the legal framework for the protected area was not in place until August 1985 (White 


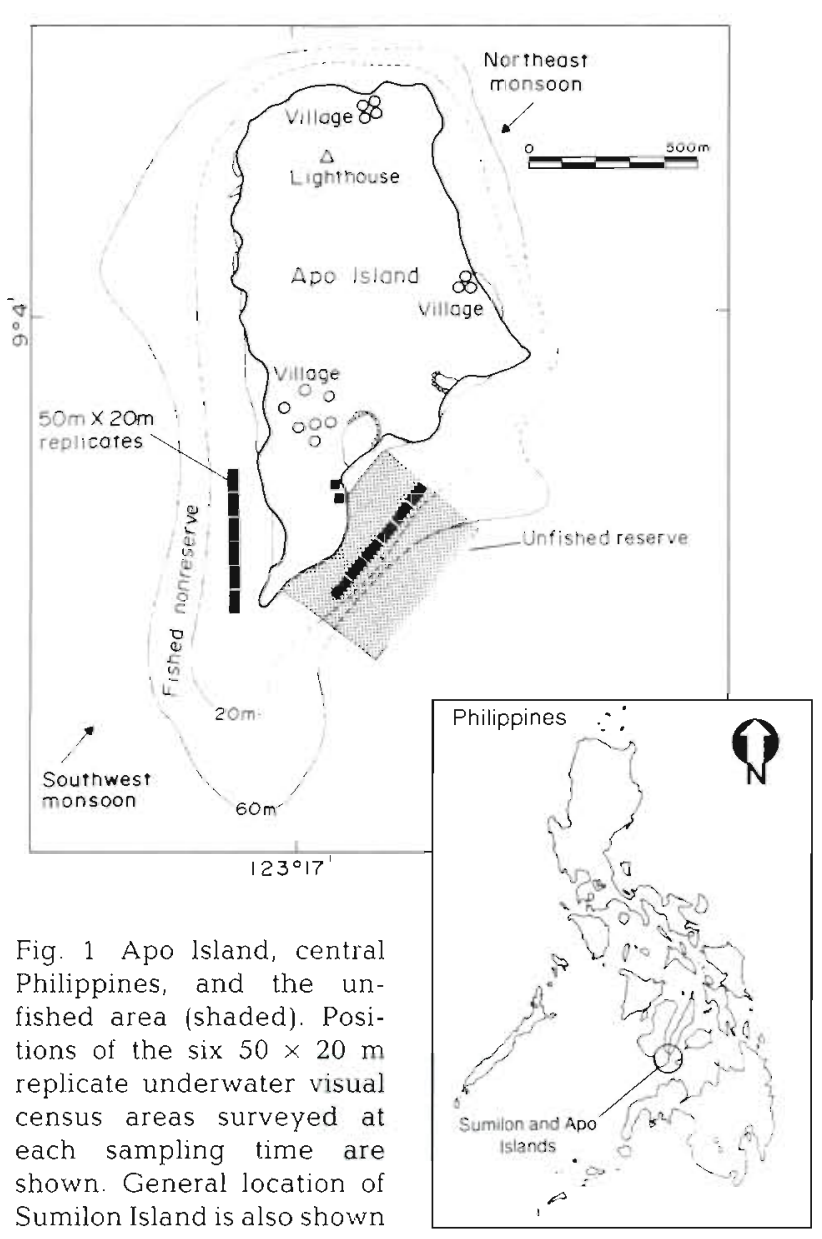

1988). The maintenance of the marine reserve has been very successful, with a local marine management committee overseeing successful protection during the period 1982-1993. The non-reserve area was open to municipal fishing (with hooks and lines, gill nets, bamboo traps and spears) throughout the study. The major activity of the 500 residents is fishing. In summary, the Apo Island reserve has been protected from fishing for 11 yr (1982-1993) and the non-reserve area was fished by approximately 200 fishers during this period. The non-reserve area of Apo is known to be subject to high fishing pressure, and the fisheries yield from the island is well known (Alcala \& Luchavez 1981, White \& Savina 1987, Bellwood 1988).

Method of visual census. Quantitative estimates of abundance of coral reef fishes were made at the 2 sites using a technique of visual census. Six replicate $50 \times$ $20 \mathrm{~m}$ censuses were made on the reef slopes of each site in December 1983,1985, 1988, 1990, 1991, 1992 and 1993. The only exception to this was that 5 replicates were censused at the Apo non-reserve site in 1983. The same replicate locations were censused each year (Fig. 1). Given the small size of the reserve and the non-reserve areas and using accurate maps of features on the coast, buoy sites and underwater features, it was usually possible to place each replicate to within \pm 5 to $10 \mathrm{~m}$ of its previous position each year. The only exception to this was that 2 replicates at the Apo non-reserve site in 1983 were located further north than shown in Fig. 1, in an area with a much higher sand cover than that of the other replicates. In 1985, these 2 replicates were abandoned and replaced by the 2 southernmost replicates shown in Fig. 1. A total of 178 species of coral reef fishes in 18 families were censused simultaneously, using underwater visual census (Russ \& Alcala 1989). However, in the present study only the data for the following families ('large predators' as a group) are presented: Serranidae (Epinephelinae) (19 spp.), Lutjanidae (11 spp.), Lethrinidae (6 spp.), and Carangidae (all species combined). All individuals of these families were identified to species (except Carangidae) and counted in each replicate census area. An individual census area was $50 \times 20 \mathrm{~m}$. An individual replicate was demarcated by laying a $50 \mathrm{~m}$ nylon tape on and parallel to the crest, defined as the point where the reef flat began to slope downward sharply, generally at an angle of more than $45^{\circ}$ A second tape was layed at one end of and perpendicular to the first, extending exactly $20 \mathrm{~m}$ down the reef slope. This demarcated a $50 \times 20 \mathrm{~m}$ area extending $50 \mathrm{~m}$ along the crest and from the crest to a depth of 14 to $17 \mathrm{~m}$, depending on the site (generally 16 to $17 \mathrm{~m}$ at the reserve site, $14 \mathrm{~m}$ at the non-reserve site). A single observer (G.R.R.) swam down the $20 \mathrm{~m}$ tape to a depth of 14 to $17 \mathrm{~m}$, began the census at this depth, and swam (using SCUBA) the $50 \mathrm{~m}$ parallel to the $50 \mathrm{~m}$ tape. The target species were counted within $3.5 \mathrm{~m}$ on either side of and $5 \mathrm{~m}$ above the observer and recorded onto prepared census sheets of waterproof paper. At the end of the $50 \mathrm{~m}$ swim, the observer moved up the slope approximately $7 \mathrm{~m}$, turned and swam $50 \mathrm{~m}$ in the opposite direction (again parallel to the $50 \mathrm{~m}$ tape), covering a second $50 \times 7 \mathrm{~m}$ strip. In this manner, 3 swims of $50 \mathrm{~m}$ length and approximately $7 \mathrm{~m}$ width censused the entire $50 \times 20 \mathrm{~m}$ area. Great care was taken to search under ledges and corals for fish. A census took approximately 40 to $50 \mathrm{~min}$ to complete. Six replicate censuses were made at each site, with each replicate separated by a distance of approximately $10 \mathrm{~m}$. The same replicate areas were censused at each site in each sampling year (Fig. 1), with the exception noted above for the Apo non-reserve. The replicate censuses were placed within approximately $10 \mathrm{~m}$ of each other at the Apo reserve site to ensure that 6 replicates would sample most of the reserve.

Analysis of data. Census times in December 1983, $1985,1988,1990,1991,1992$ and 1993 corresponded to periods of reserve protection of $1,3,6,8,9,10$ and 
11 yr, respectively. Mean density (mean of 6 replicate censuses in any year) and mean number of species of large predatory fish were plotted against years of protection for the reserve and non-reserve sites. Simple linear regression techniques were used to test if significant relationships existed between the variates. Replicates 1 and 2 of the non-reserve site (the 2 southernmost replicates; see Fig. 1) were assigned an approximate distance of 200 to $300 \mathrm{~m}$ from the southern boundary of the reserve. Similarly, Replicates 3 and 4 were assigned a distance of approximately 300 to $400 \mathrm{~m}$ from the reserve boundary and Replicates 5 and 6 were assigned a distance of approximately 400 to $500 \mathrm{~m}$ from the reserve boundary (Fig. 1). The $10 \mathrm{~m}$ spaces between replicates were ignored in these estimates since this was close to the approximate error in placement of each replicate each year (see above). Mean density of large predators at the non-reserve site was plotted against the 3 arbitrary distances from the reserve (200 to 300,300 to 400,400 to $500 \mathrm{~m}$ ) pooled for the years 1983, 1985, 1988 and 1990 and for the years 1991, 1992 and 1993. Densities were generally very low in the non-reserve area so that the total counts of large predators pooled over the periods 1983-1990 (4 survey years) and 1991-1993 (3 survey years) were examined to see if the total number of large predators observed over these periods were not significantly different from an even distribution along the non-reserve site for distances of 200 to 300,300 to 400 and 400 to $500 \mathrm{~m}$. Chi-squared tests were used to test the null hypothesis of an even distribution in space across the 3 pairs of replicates (Fig. 1).

A simple set of graphical models of change in fish density in theoretical reserve and non-reserve areas over time (where time equates to years of reserve protection) and change in the ratio of fish density in the reserve and non-reserve areas over time was constructed. Best fitting curves for the empirical data collected at the Apo reserve were used to decide which model best described the empirical data.

\section{RESULTS}

Both mean density and mean species richness of large predatory fish in the Apo reserve showed strong positive correlations with years of reserve protection $\left(r^{2}=0.95, F=85.57, p=0.0002\right.$ and $r^{2}=0.91, F=50.60$, $p=0.0009$, respectively) (Fig, 2). Such a result is perhaps to be expected, given that this group of fish is high priced and highly targeted, and fishing mortality was effectively eliminated in the reserve. However, both mean density and mean species richness of large predatory fish in the Apo non-reserve also showed strong positive correlations with years of reserve pro-

tection $\left(\mathrm{r}^{2}=0.71, F=11.98, \mathrm{p}=0.018\right.$ and $\mathrm{r}^{2}=0.81$, $F=21.59, \mathrm{p}=0.006$ ) (Fig. 2) Such a result would not a priori be expected, given that the area remained open to fishing over the study period. In fact, fishing pressure would have been expected to increase, given the natural human population increase on the island and the fact that $10 \%$ of the coral reef fishing area (i.e. the reserve) was taken out of the fishery in 1982. The result in Fig. 2 is consistent with the hypothesis that as density and species richness built up in the reserve over time, fish began to move from the reserve to the fished area, leading to the positive correlation of density and species richness with years of reserve protection in the non-reserve. An alternative hypothesis would be that Fig. 2 simply reflected a natural increase in density and species richness of large predators over the $10 \mathrm{yr}$ in the reserve and non-reserve sites land perhaps island wide), caused perhaps by successful recruitment.

However, density of large predators showed a strong upward trend in the period 1991-1993 and the majority of this increase was observed in the 2 replicates

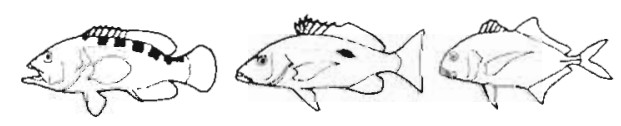

APO RESERVE
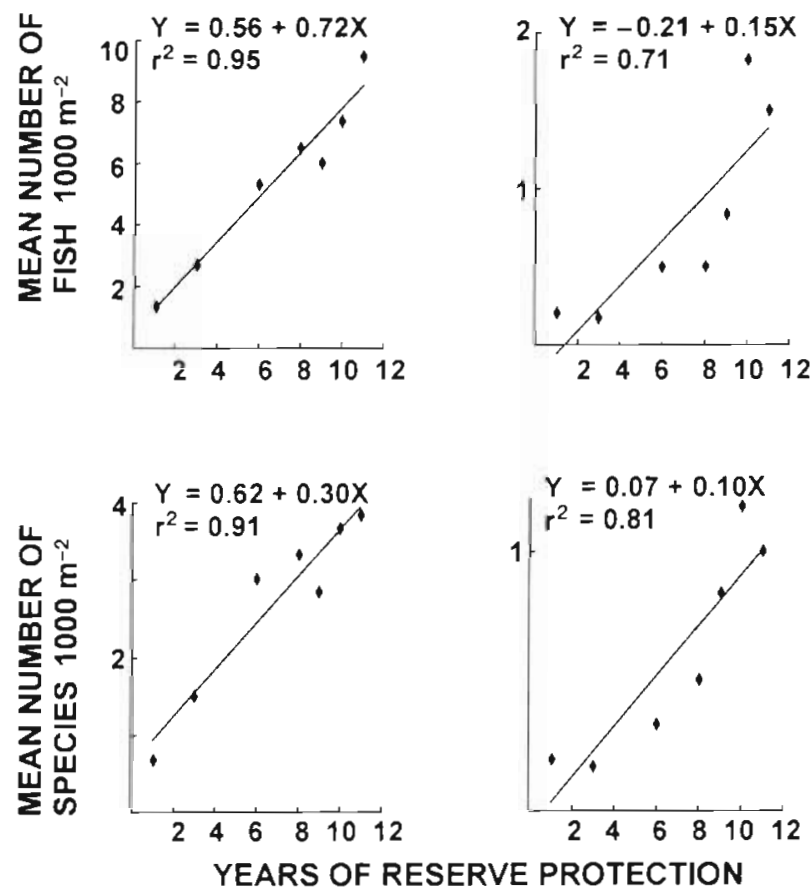

Fig. 2. Plots of mean density and mean species richness of large predatory fish (Serranidae (Epinephelinae), Lutjanıdae, Lethrinudae and Carangidae as a groupl against years of reserve protection for the Apo Island reserve and non-reserve areas. Significant positive correlations were observed for both variates both inside and adjacent to the reserve 


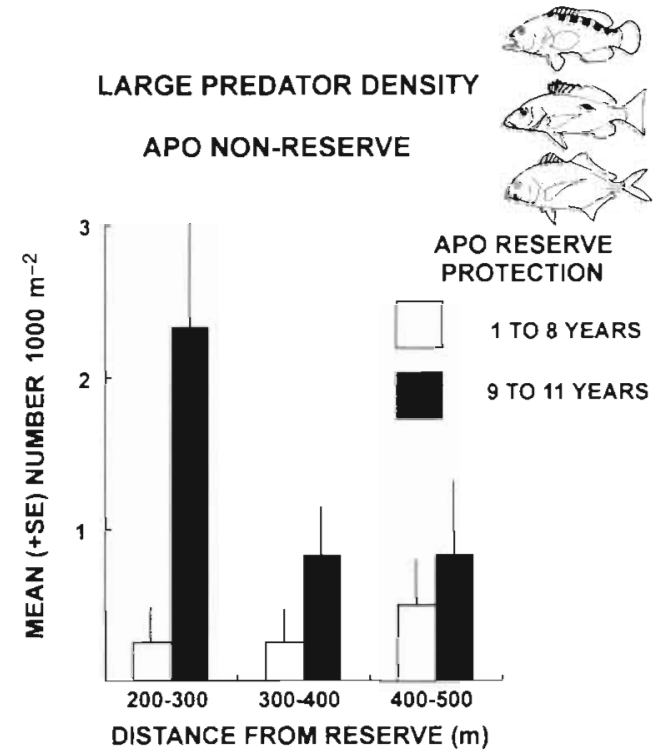

Fig. 3. Mean (+SE) density of large predatory fish [Serranidae (Epinephelinae), Lutjanidae, Lethrinidae and Carangidae as a groupl at different distances from the reserve boundary during the first 8 yr of reserve protection (4 sampling periods pooled) and the last 3 yr of reserve protection ( 3 sampling periods pooled)

closest to the reserve (Fig. 3). The total number of large predators observed over the 4 sampling periods from 1983-1990 (first 8 yr of protection) showed no significant difference from an even spatial distribution over the 3 arbitrary distances from the reserve boundary: 200 to 300,300 to 400 and 400 to $500 \mathrm{~m}$ (chi-squared with $2 \mathrm{df}=1.0, \mathrm{p}>0.05$ ) (Fig. 3 ). In contrast, the total number of large predators observed over the 3 sampling periods from 1991-1993 (Years 9 to 11 of protection) differed significantly from an even spatial distribution over the 3 arbitrary distances from the reserve (chisquared with $2 \mathrm{df}=6.7, \mathrm{p}<0.05$ ) with a significantly higher number recorded in the 2 replicates closest to the reserve boundary (Fig. 3). Such a result is inconsistent with the hypothesis of an island wide natural increase in density of large predatory fish, and consistent with the hypothesis that as density increased in the reserve over time large predators tended to move out of the reserve to the non-reserve area.

A simple set of graphical models of change in fish density in theoretical reserve and non-reserve areas over time (where time equates to years of reserve protection) and change in the ratio of fish density in the reserve and non-reserve areas over time is given in Fig. 4. Best fitting curves for the empirical data collected at the Apo reserve (Fig. 5) were consistent with Model IV in Fig. 4. Mean density of large predators in the Apo reserve increased linearly with years of reserve protection whilst the increase in mean density of large predators in the Apo non-reserve over time (1 to $11 \mathrm{yr}$ of reserve protection) was best described by an exponential curve $\left(r^{2}=0.87\right)$ (Fig. 5). The ratio of fish density in the reserve to non-reserve area started low (at around 6 after 1 yr of reserve protection), increased to high values ( 10 to 16 after 3 to 8 yr of reserve protection) and showed a distinct decline ( 5 to 8 after 9 to 11 yr of protection) (Fig. 5). A second order polynomial $\left(\mathrm{r}^{2}=0.59\right)$ appeared to describe this pattern best. Thus the pattern of change in the ratio of fish density in the reserve and non-reserve areas over time was consistent with the hypothesis that as density increased in the reserve over time, large predators tended to move out of the reserve to the non-reserve area.

\section{DISCUSSION}

The original objective of this study was to use underwater visual census to monitor the effects of marine reserve protection and fishing on populations and communities of coral reef fishes at different sites in the Philippines (see Russ 1985, Russ \& Alcala 1989, 1994). The objective of this monitoring at Apo Island was not to look for evidence of export of adult fish from the reserve to the non-reserve area (since no fish tagging program was initiated) nor to show that the presence of the reserve per se affected fisheries adjacent to the reserve (since no systematic monitoring of catch rates
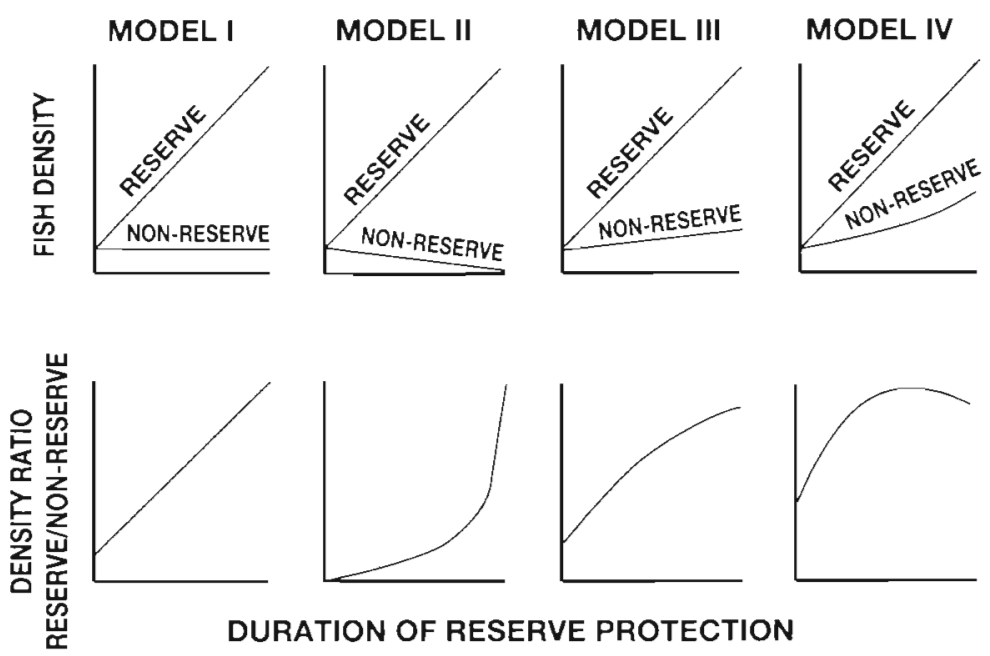

Fig. 4. A simple set of graphical models of change in fish density in theoretical reserve (no fishing) and non-reserve areas over time (where time equates to duration of reserve protection) and change in the ratio of fish density in the reserve and non-reserve areas over time 


\section{APO ISLAND LARGE PREDATORS}
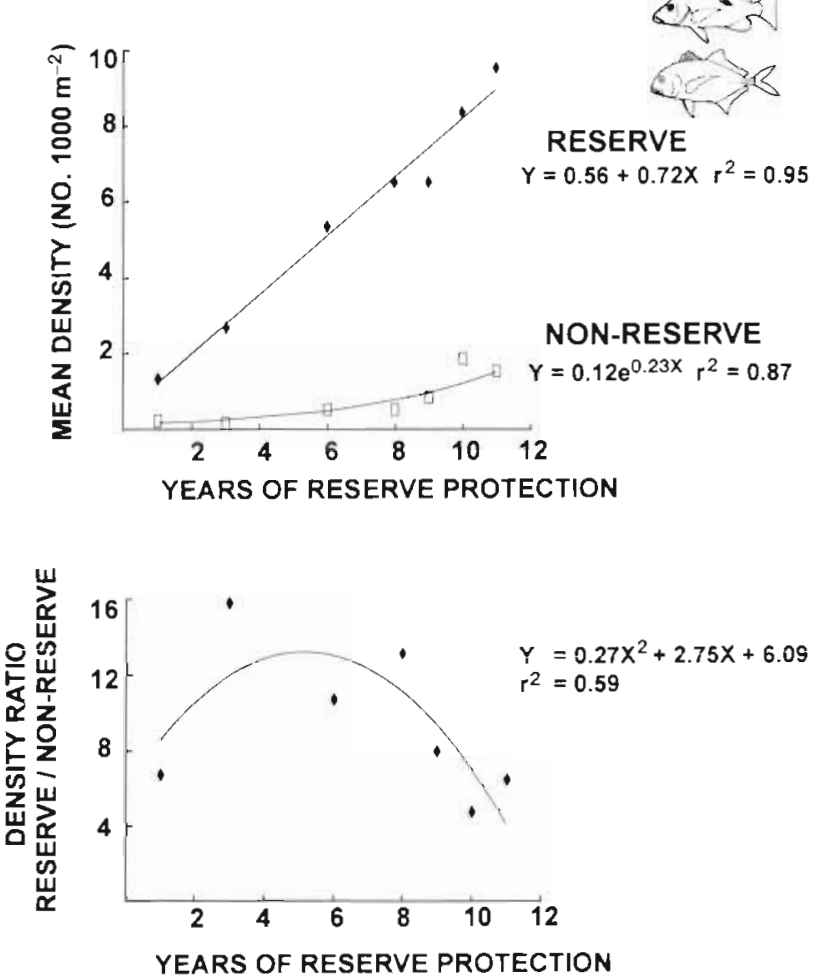

Fig. 5. Change in density of large predatory fish [Serranidae (Epinephelinae), Lutjanidae, Lethrinidae and Carangidae as a group] with years of reserve protection in both the reserve and non-reserve areas of Apo Island. Resultant change in the ratio of fish density in the reserve to non-reserve area with duration of reserve protection is also shown

close to and far from the reserve was initiated) Furthermore, the selection of the location of the nonreserve site in this study was based more on achieving relatively similar habitat characteristics to the reserve area (but being open to fishing) rather than placing the non-reserve site at a predetermined distance from the reserve. Thus, the results obtained in this study supporting the hypothesis of export of adult fish from the reserve to the non-reserve area are somewhat fortuitous.

Significant positive correlations of both mean density and species richness of large predatory fish with duration of reserve protection (from 1 to $11 \mathrm{yr}$ ) were observed in both the reserve and non-reserve areas surveyed (Fig. 2). The result in Fig. 2 is consistent with the hypothesis that as density and species richness built up in the reserve over time, fish began to move from the reserve to the fished area, leading to the positive correlations of density and species richness with years of reserve protection in the non-reserve. An alternative hypothesis would be that Fig. 2 simply reflected an island wide, natural increase in density and species richness of large predators over the $10 \mathrm{yr}$. caused perhaps by prolonged, successful recruitment. However, the visual census data demonstrated that the build up of density and species richness of large predators in the non-reserve area was most pronounced nearest to the reserve (Fig 3). There were no obvious differences in the characteristics of the benthic habitat between this area closest to the reserve and those replicate areas further from the reserve both early (1983) and late (1993) in the study. Thus, the visual census data is inconsistent with the hypothesis of an island wide natural increase in density of large predatory fish and is consistent with a proposed model of adult fish export from the reserve to the non-reserve. Under the favoured model (Model IV in Fig. 4), the ratio of density of fish in the reserve and non-reserve areas should increase and then decrease as the duration of reserve protection proceeds, a pattern observed at Apo Island (Fig. 5). The data do, however, suggest that the effect of export of adult fish biomass may be slow to develop (up to $8 \mathrm{yr}$ in this study) and perhaps be important only on scales of a few hundred metres.

It is important to realize that visual census is likely to underestimate the potential significance of fish export to the local fishery (even in the absence of any differences in sightability of fish in fished and unfished areas) since it will detect only fish in excess of those caught. The first effect to be expected if fish are being exported from the reserve might be an increase in the catch rate close to the reserve boundary, an effect that would likely result in increased fishing effort in this area, eliminating or reducing any increase in stock density near the reserve boundary. This effect would be analogous to a functional response of a predator to increased availability of prey. Eventually the predator (the fishery) may become satiated, allowing a build up of stock density (large enough to be detected by visual census) near the reserve boundary only after a delay period. Furthermore, there may be some 'critical density' inside the reserve above which large-scale movement or emigration is more probable. Such a process would also result in a delay before fish were exported from a reserve. In the present study, there is no way of differentiating between these 2 processes. However, the delay period before a strong increase in density of large predatory fish was detected with visual census was 9 to 11 yr in the present study (see Fig. 5).

Particularly relevant results on trends in the fishery supplemental to the visual census data discussed above have been produced by White \& Calumpong (1992). They provided a summary of interviews on the attitudes and perceptions of fishers regarding the marine reserve at Apo Island in 1986 and 1992 (their Table 14). In 1986 (after approximately 4 yr of reserve 
protection) 11 of 12 fishers interviewed perceived their catch to have increased and in 1992 (after approxi. mately 10 yr of reserve protection) 21 of 21 fishers said that their catch had at least doubled since 1985. If fishing efforts were assumed to be evenly distributed around the island before the reserve was in place, and if it was assumed that the reserve had no effect on local fisheries, this would imply that, with $10 \%$ of the fishing area taken away, yields would actually decrease. That there was unanimous agreement among the fishers that yields increased despite the fact that $10 \%$ of the fishing grounds were unavailable strongly implies that the reserve effect has more than compensated for the loss of fishing area. This evidence, coupled with the data presented in this paper, provides strong circumstantial evidence that the reserve may be exporting adult fish biomass to adjacent fished areas and that such export may be assisting local fisheries. As a group, the large predators [Serranidae (Epinephelinae), Lutjanidae, Lethrinidae and Carangidae] constitute 25 to $45 \%$ of reef fisheries yield, with carangids accounting for $90 \%$ of this (Alcala \& Luchavez 1981, White \& Savina 1987, Bellwood 1988).

The evidence for populations of target species in marine reserves replenishing target species outside the reserve by the process of adult (post-settlement) movement (the so-called 'spillover effect') is limited (see reviews by Davis 1981, 1989, Roberts \& Polunin 1991, 1993, Dugan \& Davis 1993, Rowley 1994). The evidence consists of a study that demonstrated enhanced catch rates in a fished area surrounding a reserve after 5 yr of reserve protection and demonstrated movement from the unfished to the fished area (Yamasaki \& Kuwahara 1990, studying snow crabs in Japan) and a second that demonstrated a significant decline in catch rates and total catch after a marine reserve (of almost $10 \mathrm{yr}$ of protection) was heavily fished, suggesting that migration of fish from the reserve to the non-reserve area during protection was enhancing fisheries yield (Alcala \& Russ 1990, studying coral reef fishes at Sumilon Island, The Philippines). In addition, a reasonable number of studies have specifically tried to demonstrate movement of target species from marine reserves to fished areas using tag-recapture techniques, e.g. lobsters (Davis \& Dodrill 1980, 1989), shrimps (Gitschlag 1986), snow crabs (Yamasaki \& Kuwahara 1990) and reef fish (Beinssen 1989, 1990, Bryant et al. 1989, Buxton \& Allen 1989, Rutherford et al. 1989, Holland et al. 1993, Attwood \& Bennet 1994, Davies 1995). In addition, several studies have modeled the potential effects of movements of adult fish from marine reserve to fished areas on yield per recruit of target species (Polacheck 1990, Russ et al. 1992, DeMartini 1993).
The establishment of a no-fishing sanctuary that covered $2 \%$ of the fishing ground for snow crabs in Japan led to a $46 \%$ increase in mean catch per unit effort in areas adjacent to the sanctuary after 5 yr of sanctuary protection (Yamasaki \& Kuwahara 1990). This increase in catch rate was reported to be most evident within 3 miles (ca $5 \mathrm{~km}$ ) of the boundary of the sanctuary. In addition, Yamasaki \& Kuwahara (1990) used tag-recapture techniques to demonstrate dispersal of male snow crabs from the sanctuary to fished areas. A marine reserve protecting $25 \%$ of the $0.5 \mathrm{~km}^{2}$ of coral reef surrounding Sumilon Island in the central Philippines from municipal fishers was established in 1974. Fishery yields (gear: traps, hooks and lines, gill nets and spears) were monitored for 6 separate years (during the period 1976-1983/84) in the fished area of the reef, and there was some evidence of yields gradually increasing, particularly for traps (see Alcala 1981 and Fig. 4 in Aicala \& Russ 1990). In 1984, the marine reserve was pulse fished, resulting in significant declines of those species which constituted the majority of the reef fishery yield (principally caesionids; Russ \& Alcala 1989, Alcala \& Russ 1990). This resulted in significant reductions in the catch rates and a $54 \%$ decline in total catch in 1985/86, 18 mo after the reserve was fished (Alcala \& Russ 1990). It was argued that protection of the reserve maintained high abundances of fishes in the reserve and significantly higher yields to fishers in areas adjacent to the reserve. Alcala \& Russ (1990) suggested that migration of adult fish from the reserve to the non-reserve during protection was the simplest explanation for this result, although they did not strengthen their case by demonstrating such movement with tagging studies.

In the first experimental investigation of the potential effects of marine reserves on fishery harvests, Davis (1977) showed that when a section of a $95 \mathrm{~km}^{2}$ marine reserve in Florida (USA) which had been protected for 29 mo was opened to recreational fishers, abundance of spiny lobsters Panulirus argus declined by $60 \%$ and catch rates of experimental traps in this area were $22 \%$ below preharvest levels 12 mo after complete protection was reimposed. Thus, Davis (1977) demonstrated that closure could increase abundance and that such increases could be eroded quickly when fished. In the same study, Davis (1977) demonstrated that lobsters were capable of dispersing up to $10 \mathrm{~km}$ but was unable to demonstrate enhanced yield in an area adjacent to an area of $19 \mathrm{~km}^{2}$ that had been permanently protected. In subsequent studies, Davis \& Dodrill $(1980,1989)$ used tag-recapture studies to demonstrate that spiny lobsters do move from reserve to fished areas. Dugan \& Davis (1993) also report a study by Gitschlag (1986) in which tag-recapture techniques demonstrated movement of shrimp from the Tortugas sanctuary (Florida, USA) to adjacent fished areas. 
Several studies have used tag-recapture techniques to estimate the amount of movement of reef fish from reserve to non-reserve areas (Beinssen 1989, 1990, Buxton \& Allen 1989, Holland et al. 1993, Attwood \& Bennet 1994, Davies 1995). This subject was reviewed recently by Roberts \& Polunin (1991) and Robertson (1988). Roberts \& Polunin (1991) provided a general review of the extent of movement of adult reef fish. Bryant et al. (1989) and Rutherford et al. (1989) used tag-recapture studies to demonstrate that severa] species of reef fish moved out of the Everglades National Park in Florida Bay seasonally and that Lutjanus griseus moved, on average, $18.3 \mathrm{~km}$, with the movement apparently related to an ontogenetic shift in habitat preference. Buxton \& Allen (1989) tagged 464 individuals of 2 species of sparid in the Tsitsikamma Coastal National Park in South Africa. Of the 12 individuals recaptured, all were within $2 \mathrm{~km}$ of their release point and none had moved out of the park. Beinssen (1989) showed that $29 \%$ of tagged individuals of the serranid Plectropomus leopardus moved distances of up to $500 \mathrm{~m}$ in $3 \mathrm{wk}$, with movements recorded from an unfished to a fished area of Heron Island reef on the Great Barrier Reef, Australia. A second survey 3 mo after the initial releases (Beinssen 1990) suggested that the overall density of $P$. leopardus had decreased by almost $50 \%$ and that dispersion throughout the study site had continued. Davies (1995) investigated the movement of the same species studied by Beinssen (1990) between and within 5 coral reefs of the Great Barrier Reef. Davies (1995) concluded that less than $1 \%$ of the tagged population of 4627 fish moved between reefs but that movement within reefs was considerable. Over a period of $22 \mathrm{mo}, 26 \%$ of tagged fish moved distances within reefs of 2 to $2.5 \mathrm{~km}$, $7 \%$ distances of 2.5 to $5 \mathrm{~km}$, and $2 \% 5$ to $7.5 \mathrm{~km}$. Holland et al. (1993) working in Hawaii (USA) used conventional tag-recapture and ultrasonic telemetry to show that the mullid Mulloides flavolineatus demonstrated high site fidelity but exhibited crepuscular movements away from daytime schooling sites to nighttime feeding grounds up to $600 \mathrm{~m}$ away. The only movements out of a $137 \mathrm{~km}^{2}$ no-fishing conservation zone were related to summer spawning migrations (Holland et al. 1993). Virtually all of these tag-recapture studies confirmed that reef fish, particularly large predatory reef fish, are certainly likely to move over distances of a few hundred metres to a kilometre or more and that such fish may move considerably larger distances during ontogenetic shifts in habitat preference or during spawning migrations. Roberts \& Polunin (1991) concluded that considerable potential exists for movement of adult fish across reserve boundaries but that any significant enhancement of fisheries by emigration would be expected ta be over dis- tances of less than $1 \mathrm{~km}$. The results of the present study, based on visual census data, support this suggestion.

Three recent studies have modeled the potential effects of marine reserves on yield per recruit of fishes in areas adjacent to reserves (Polacheck 1990, Russ et al. 1992, DeMartini 1993). These studies expanded on the original theory of Beverton \& Holt (1957) which was developed to adjust yield estimates in stocks which could potentially move between fished and unfished areas. All 3 of the studies found that permanent reserves could moderately increase yield per recruit, but only if very high fishing mortalities existed outside the reserve and only at relatively high rates of transfer of fish. In a very detailed set of simulations, DeMartini (1993) investigated the effect of marine reserves on yield per recruit of 3 'model' types of coral reef fish over a range of reserve sizes, transfer rates and fishing mortalities. Not only did he conclude that marine reserves would be likely to increase yield per recruit only at high levels of fishing mortality and high transfer rates, but that any enhancement would be likely to be restricted to the area close to the reserve.

In conclusion, the results of this study at Apo Island are consistent with a proposed model of export of adult fish from reserve to adjacent non-reserve sites. Based on visual census data, this effect may be slow to develop (up to $8 \mathrm{yr}$ in this study) and perhaps be important only on scales of a few hundred metres. To conclude unequivocally that marine reserves can maintain or enhance fisheries in adjacent areas will require proper experimental. and sampling designs. Key elements in such designs will include non-reserve (control) sites at predetermined distances from the reserve boundaries (including sites at distances unlikely to be affected by the presence of a reserve), monitoring of catch per unit effort at all control sites before and during reserve protection, use of tag-recapture techniques to establish the extent, if any, of export, and use of visual census techniques at reserve and all control sites to test if the density ratio of fish in the reserve and adjacent non-reserve sites conforms to the model presented in this paper.

Acknowledgements. Some financial support for this research was provided by the United Nations Environment Program and the Natural Resources Management Center of the Philippines (1983) and the Great Barrier Reef Marine Park Authority (1985). Thanks to all of the staff at the Marine Laboratory, Silliman University, Dumaguete City, Philippines and to the people of Apo Island. J. McManus and D. Pauly kindly read the manuscript. C. Banao drew Fig. 1. The data were analyzed and the paper written whilst G.R.R. was on study leave at the International Center for Living Aquatic Resources Management (ICLARM). Thank you to all at ICLARM, in particular J. Maclean, J. McManus, J. Munro, D. Pauly and R. Pullin, for useful discussions 


\section{LITERATURE CITED}

Alcala AC (1981) Fish yields of coral reefs of Sumilon Island, central Philippines. Natl Res Counc Philipp Res Bull 36:1-7

Alcala AC, Luchavez T (1981) Fish yield of the coral reef surrounding Apo Island, central Visayas, Philippines. Proc 4th int Symp Coral Reefs 1:69-73

Alcala AC, Russ GR (1990) A direct test of the effects of protective management on abundance and yield of tropical marine resources. J Cons int Explor Mer 46:40-47

Attwood CG, Bennet BA (1994) Variation in dispersal of galjoen (Coracinus capensis) from a marine reserve. Can J Fish Aquat Sci 51:1247-1253

Beinssen K (1989) Heron reef demersal reef fish movement study. Report to the Qld Department of Conservation, Parks and Wildlife, Rockhampton, Qld, Australia

Beinssen K (1990) Heron reef demersal reef fish movement study, update on September 1989 Interim report. Report to the Qld Department of Conservation, Parks and Wildlife, Rockhampton, Qld, A.ustralia

Bellwood DR (1988) Seasonal changes in the size and composition of the fish yield from reefs around Apo Island, central Philippines, with notes on methods of yield estimation. J Fish Biol 32:881-893

Beverton RJH, Holt SJ (1957) On the dynamics of exploited fish populations. Fisheries Investment Series 2, Vol 19. UK Ministry of Agriculture and Fisheries, London

Bohnsack JA (1990) The potential of marine fishery reserves for reef fish management in the U.S. south Atlantic. NOAA Tech Memo NMFS-SEFC 261:1-40

Bohnsack JA. (1993) Marine reserves: they enhance fisheries, reduce conflicts, and protect resources. Océanus 36(3):63-71

Bryant HE, Dewey MR, Funicelli NA, Meineke DA, Mengel J (1989) Movement of five selected species of fish in the Everglades National Park. Abstract. Bull mar Sci 44:515

Buxton CD, Allen JA (1989) Mark and recapture studies of two reef sparids in the Tsitsikamma Coastal National Park. Koedoe 32:39-45

Cabanban AS, White AT (1981) Marine conservation program using non-formal education at Apo Island, Negros Oriental, Philippines. Proc 4th int. Symp Coral Reefs 1:317-321

Carpenter KE (1977) Philippine coral reef fisheries resources. Philipp J Fish 15:95-126

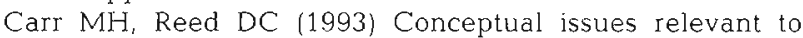
marine harvest refuges: examples from temperate reef fishes. Can J Fish Aquat Sci 50:2019-2028

Davies CR (1995) Patterns of movement of three species of coral reef fish on the Great Barrier Reef. PhD thesis, James Cook University of North Queensland, Townsville

Davis GE (1977) Fishery harvest in an underwater park. Proc 3rd int Symp Coral Reefs 2:605-608

Davis GE (1981) On the role of underwater parks and sanctuaries in the management of coastal resources in the southeastern United States. Environ Conserv 8:67-70

Davis GE (1989) Designated harvest refugia: the next stage of marine fishery management in California. Calif coop ocean Fish Invest Rep 30:53-58

Davis GE, Dodrill JW (1980) Marine parks and sanctuaries for spiny lobster fishery management. Proc Gulf Caribb Fish Inst 32:194-207

Davis GE, Dodrill JW (1989) Recreational fishery and population dynamics of spiny lobster, Panulirus argus, in Florida Bay, Everglades Nationa] Park, 1977-1980. Bull mar Sci44:78-88

DeMartini EE (1993) Modeling the potential of fishery reserves for managing Pacific coral reef fishes. Fish Bull US $91: 414-427$

Dugan JE, Davis GE (1993) Applications of marine refugia to coastal fisheries management. Can J Fish Aquat Sci 50: 2029-2042

Gitschlag GR (1986) Movement of pink shrimp in relation to the Tortugas sanctuary. N Am J Fish Manage 6:328-338

Holland KN, Peterson JD, Wetherbee BM (1993) Movements, distribution and growth rates of the white goatfish $\mathrm{Mul}$ loides flavolineatus in a fisheries conservation zone. Bull mar Sci 52:982-992

Mar A, Law R, Polunin NVC (1995) Role of marine reserves in recruitment to reef fisheries: a metapopulation model. Biol Conserv 71:197-204

McManus JW (1988) Coral reefs of the ASE AV region: status and management. Ambio 17.189-193

Murdy EO, Ferraris CJ (1980) The contribution of coral reef fisheries to Philippine fisheries production. ICLARM Newslett 3:21-22

Polacheck T (1990) Year round closed areas as a management tool. Nat Resour Model 4:327-354

Polunin NVC (1990) Marine regulated areas: an expanded approach for the tropics. Resour Manage Optim 7:283-299

Polunin NVC, Roberts CM (1993) Greater biomass and value cf target coral-reef fishes in two small Caribbean marine reserves. Mar Ecol Prog Ser 100:167-176

Roberts CM, Polunin NVC (1991) Are marine reserves effective in management of reef fisheries? Rev Fish Biol Fish 1:65-91

Roberts CM, Polunin NVC (1993) Marine reserves: simple solutions to managing complex fisheries? Ambio 22:363-368

Robertson DR (1988) Abundances of surgeonfishes on patch reefs in Caribbean Panama: due to settlement or postsettlement events? Mar Biol 97:495-501

Rowley RJ (1994) Marine reserves and fisheries management. Aquat Conserv 4:233-254

Russ GR (1985) Effects of protective management on coral reef fishes in the central Philippines. Proc 5th int Coral keefs Congr $4: 219-224$

Russ GR (1991) Coral reef fisheries: effects and yields. In: Sale FF (ed) The ecology of fishes on coral reefs. Academic Press, San Diego, p $601-635$

Russ GR, Alcala AC (1989) Effects of intense fishing pressure on an assemblage of coral reef fishes. Mar Ecol Prog Ser 56:13-27

Russ GR, Alcala AC (1994) Sumilon island reserve: 20 years of hopes and frustrations. NAGA ICLARM Q 7(3):8-12

Russ GR, Alcala AC, Cabanban AS (1992) Marine reserves and fisheries management on coral reefs with preliminary modeling of the effects on yield per recruit. Proc 7 th int Symp Coral Reefs 2:988-995

Rutherford ES, Tilmant JT, Thue EB, Schmidt TW (1989) Fishery harvest and population dynamics of gray snapper, Lutjanus griseus, in Florida Bay and adjacent waters. Bull mar Sci 44:139-154

White AT (1988) Marine parks and reserves. Management for coastal environments in Southeast Asia. ICLARM Ed Ser $2: 1-36$

White AT, Calumpong H (1992) Summary field report. Saving Tubbataha Reef. Monitoring marine reserves in the central Visayas. Report, Earthwatch Expedition, Dumaguete City, Philippines, April-May 1992

White AT, Hale LZ, Renard Y, Cortesi L (1994) Collaborative and community-based management of coral reefs. Lessons from experience. Kumarian Press, CT, p 1-121

White AT, Savina GC (1987) Reef fish yield and non-reef catch of Apo Island, Negros, Philippines. Asian Mar Biol 4:67-76

Yamasaki A, Kuwahara A (1990) Preserved area to effect recovery of overfished Zuwai crab stocks off Kyoto Prefecture. In: Proceedings of the International Symposium on King and Tanner Crabs. Alaska Sea Grant College Program, University of Alaska, Fairbanks, p 575-578 